\title{
Combined branch retinal vein and artery occlusion in toxoplasmosis
}

\author{
Oclusão combinada de ramo arterial e venoso retinianos em toxoplasmose
}

\author{
Fabio Bom Aggio ${ }^{1}$, Fernando José de Novelli ${ }^{1}$, Evandro Luis Rosa ${ }^{1}$, Mário Junqueira Nobrega ${ }^{1}$
}

\begin{abstract}
A 22-year-old man complained of low visual acuity and pain in his left eye for five days. His ophthalmological examination revealed $2+$ anterior chamber reaction and a white, poorly defined retinal lesion at the proximal portion of the inferotemporal vascular arcade. There were retinal hemorrhages in the inferotemporal region extending to the retinal periphery. In addition, venous dilation, increased tortuosity, and ischemic retinal whitening along the inferotemporal vascular arcade were also observed. A proper systemic work-up was performed, and the patient was diagnosed with ocular toxoplasmosis. He was treated with an anti-toxoplasma medication, and his condition slowly improved. Inferior macular inner and middle retinal atrophy could be observed on optical coherence tomography as a sequela of ischemic injury. To our knowledge, this is the first report of combined retinal branch vein and artery occlusion in toxoplasmosis resulting in a striking and unusual macular appearance.
\end{abstract}

Keywords: Ocular toxoplasmosis; Uveitis; Retinal artery occlusion; Retinal vessels; Visual acuity; Optical coherence tomography; Vision disorders

\begin{abstract}
RESUMO
Um paciente do sexo masculino, com 22 anos de idade, queixou-se de redução da acuidade visual no ol ho esquerdo por 5 dias. O exame oftalmológico mostrou reação de câmara anterior $2+$ e uma lesão retiniana esbranquiçada, pouco definida, na porção proximal da arcada vascular temporal inferior. Foram observadas hemorragias retinianas na regiäo temporal inferior estendendo-seà periferia, assim como ingurgitamento venoso, aumento da tortuosidade e palidez isquêmica da retina no mesmo quadrante. Exames laboratoriais corroboraram o diagnóstico de toxoplasmose ocular. O paciente melhorou lentamente após tratamento apropriado. Foi evidenciada atrofia da retina macular inferior interna e média à tomografia de coerência óptica, como sequela da isquemia retiniana. Para nosso conhecimento, este é o primeiro relato de oclusão retiniana combinada de ramo arterial e venoso em toxoplasmose ocular, levando a um aspecto fundoscópico atípico e peculiar.
\end{abstract}

Descritores: Toxoplasmose ocular; Uveites; Oclusão da artéria retiniana; Vasos retinianos; Acuidade Visual; Tomografia de coerência óptica; Transtornos da visão

\section{INTRODUCTION}

Toxoplasmosis is the leading cause of infectious posterior uveitis worldwide, accounting for $80 \%$ of the cases in some regions ${ }^{(1)}$. Although toxoplasmic retinochoroiditis usually has a self-limiting course, it can lead to an irreversible visual loss, particularly when the macula and optic nerve head are involved. Vascular involvement typically consists of diffuse or segmental sheathing produced by antigen-antibody complex deposition in the vessel wall, as well as by localized mononuclear cell infiltrates ${ }^{(1)}$. Retinal vein occlusion may occur, but artery obstruction is rare ${ }^{(2-4)}$. We herein report an atypical presentation of toxoplasmic retinochoroiditis characterized by the occurrence of combined branch retinal vein and artery occlusion.

\section{CASE REPORT}

A 22-year-old healthy man complained of low visual acuity and pain in his left eye [oculus sinister (OS)] for five days. His past ocular and family history were unremarkable. Best-corrected visual acuity (BCVA) was 20/20 in the right eye [oculus dexter (OD)] and 20/400 in the left eye (OS). His anterior segment examination was normal OD and revealed $2+$ anterior chamber reaction OS. Intraocular pressure by applanation tonometry was $10 \mathrm{mmHg}$ in both eyes at 08:00. Funduscopy showed a normal OD and a white, poorly demarcated, and slightly elevated retinal lesion at the proximal portion of the inferotemporal vascular arcade OS. There were retinal hemorrhages in the inferotemporal region extending to the periphery with venous dilation and increased tortuosity, as well as ischemic retinal whitening along the inferotemporal vascular arcade, $2+$ vitreous cells, and diffuse periphlebitis. The striking macular appearance was reminiscent of viral retinitis, given its necrotic and hemorrhagic features (Figure 1).
Blood tests revealed normal leukocyte and erythrocyte counts and erythrocyte sedimentation rates. Serological tests for human immunodeficiency virus (HIV) and syphilis (venereal disease research laboratory and fluorescent treponemal antibody absorption tests) were negative. Chest X-ray films were normal. Toxoplasma immunoglobulin (Ig) G antibodies were positive in an enzyme-linked immunosorbent assay $(132 \mathrm{lU} / \mathrm{mL}$ ), whereas anti-toxoplasma IgM antibodies were negative.

Two days after initial presentation, the patient was started on pyrimethamine at $50 \mathrm{mg}$ daily, sulfadiazine at $2 \mathrm{~g}$ daily, folinic acid at $15 \mathrm{mg}$ three times a week, prednisone at $60 \mathrm{mg}$ daily, in a tapering schedule, as well as topical prednisolone acetate $1 \%$ and tropicamide $1 \%$. Five days later, BCVA was maintained, and the ophthalmologic examination did not reveal any changes. Three weeks later, BCVA was 20/150 OS. His anterior segment examination was unchanged OD and showed $1+$ anterior chamber reaction OS. Intraocular pressure was $16 \mathrm{mmHg}$ OD and $14 \mathrm{mmHg}$ OS. Funduscopy was unchanged OD and showed a well-demarcated, whitish inferotemporal retinochoroidal lesion. There was sheathing of the inferotemporal retinal artery, mild juxtafoveal inferior retinal whitening, a macular star, and $1+$ vitreous cells (Figure 2, left). Six weeks after the beginning of treatment, BCVA was 20/30 OS. There was no anterior chamber or vitreous cells. The inferotemporal retinochoroidal lesion showed signs of scarring (Figure 2, middle). Oral medication was discontinued, and the prednisolone acetate $1 \%$ drops were tapered.

Three months after the initial presentation, BCVA was 20/30 OS. His anterior segment examination revealed no changes. The intraocular pressure was $16 \mathrm{mmHg} O D$ and $15 \mathrm{mmHg}$ OS. Funduscopy showed an inferotemporal retinochoroidal scar and partial resolution
Submitted for publication: April 1, 2015

Accepted for publication: June 18, 2015

${ }^{1}$ Hospital de Olhos Sadalla Amin Ghanem, Joinville, SC, Brazil.
Funding: No specific financial support was available for this study

Disclosure of potential conflicts of interest: None of the authors have any potential conflict of interest to disclose.

Corresponding author: Fabio Bom Aggio. Rua Camboriú, 35 - Joinville - SC - 89216-222 - Brazil E-mail: fabioaggio@me.com 
of the macular star (Figure 2, right). Fluorescein angiography revealed focal hypofluorescence with surrounding early hyperfluorescence corresponding to the inferotemporal scar and blocked hypofluorescence corresponding to the retinal hemorrhages. No areas of non-perfusion were detected (Figure 3). Optical coherence tomography showed signs of partial posterior hyaloid detachment, inferior macular inner and middle retinal atrophy, hyperreflective intraretinal dots superior to the fovea corresponding to the hard exudates, as well as a mild foveal discontinuity of the outer retina and pigment epithelium layer (Figure 4).

\section{DISCUSSION}

The diagnosis of ocular toxoplasmosis is usually straightforward; however, challenging cases may occur. In the case presented here, vascular occlusion of the inferotemporal retinal artery and vein led to unusual fundus findings characterized by ischemic retinal whitening and numerous scattered retinal hemorrhages obscuring the boundaries of the focal inflammatory lesion. The appearance of the fundus resembled viral retinitis. Considering the high prevalence of toxoplasmosis in $\operatorname{Brazi}^{(5)}$, the health status of the patient, and absence of peripheral retinitis, toxoplasmosis was strongly suspected. An anti-toxoplasma medication was introduced, and the patient was closely followed.
Ocular toxoplasmosis begins in the superficial retina. As retinitis progresses, the involvement of full-thickness retina, adjacent choroid, vitreous, and even sclera may occur. The initial lesion with ill-defined margins due to retinal edema tends to become more defined with treatment. After a variable time period, pigmentation mainly occurs in the lesion margins ${ }^{(1)}$. These findings were observed in our case.

Vascular changes in toxoplasmosis typically involve veins, but arteries may also be affected, particularly in the form of Kyrieleis arteritis ${ }^{(1)}$, characterized by nodular periarterial plaques that were observed in our case (Figure 2). Although classically described in toxoplasmosis, Kyrieleis arteritis may occur in syphilis, rickettsial retinal vasculitis, acute retinal necrosis, and other diseases. Its presence should raise suspicion of an infectious cause of retinal vasculitis ${ }^{(1)}$.

Branch artery occlusion may result from direct artery compression by retinochoroiditis or by arteriolar contraction associated with increased viscosity of blood and inhibition of coagulation due to heparin release from mast cells as a response to acute inflammatory stimuli. It may also be a consequence of perivasculitis, which may cause thickening of the vessel wall, disruption of blood flow, and thrombosis(6). Yu et al. ${ }^{(7)}$ identified the following three patterns of retinal capillary ischemia using optical coherence tomography in arterial occlusive disease in the acute phase: (1) thickening and hyperreflectivity of the inner retinal layers owing to ischemia of the superficial capillary plexus, (2) hyperreflective band at the level of the inner nuclear layer represen-
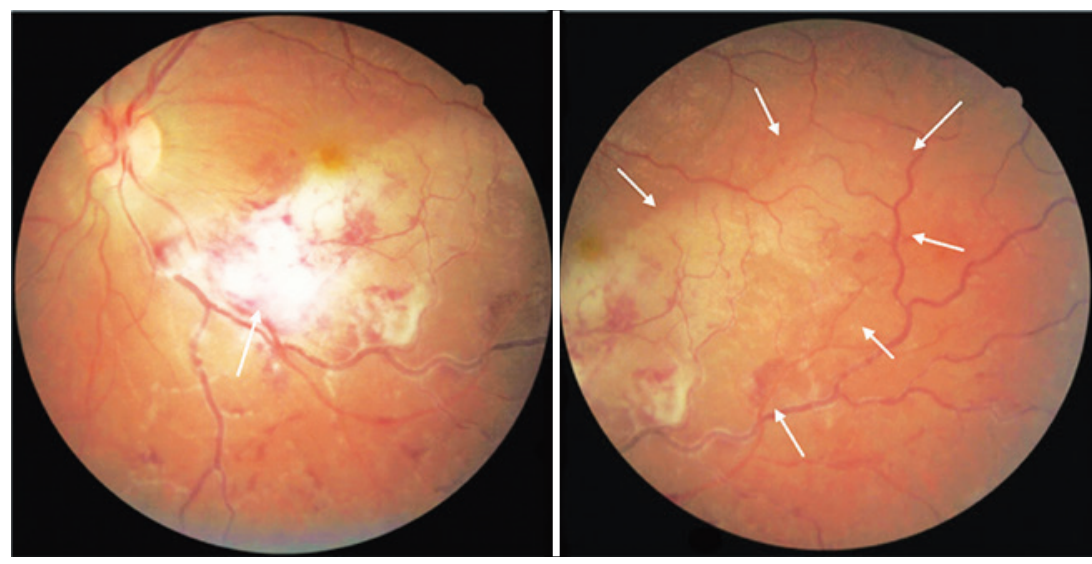

Figure 1. Initial presentation: Fundus photography of the left eye showing a white, poorly demarcated, and slightly elevated retinal lesion at the proximal portion of the inferotemporal vascular arcade (arrow, left). There were retinal hemorrhages in the inferotemporal region extending to the periphery with venous dilation and increased tortuosity, as well as ischemic retinal whitening along the inferotemporal vascular arcade (arrows, right), 2+ vitreous cells, and diffuse periphlebitis.
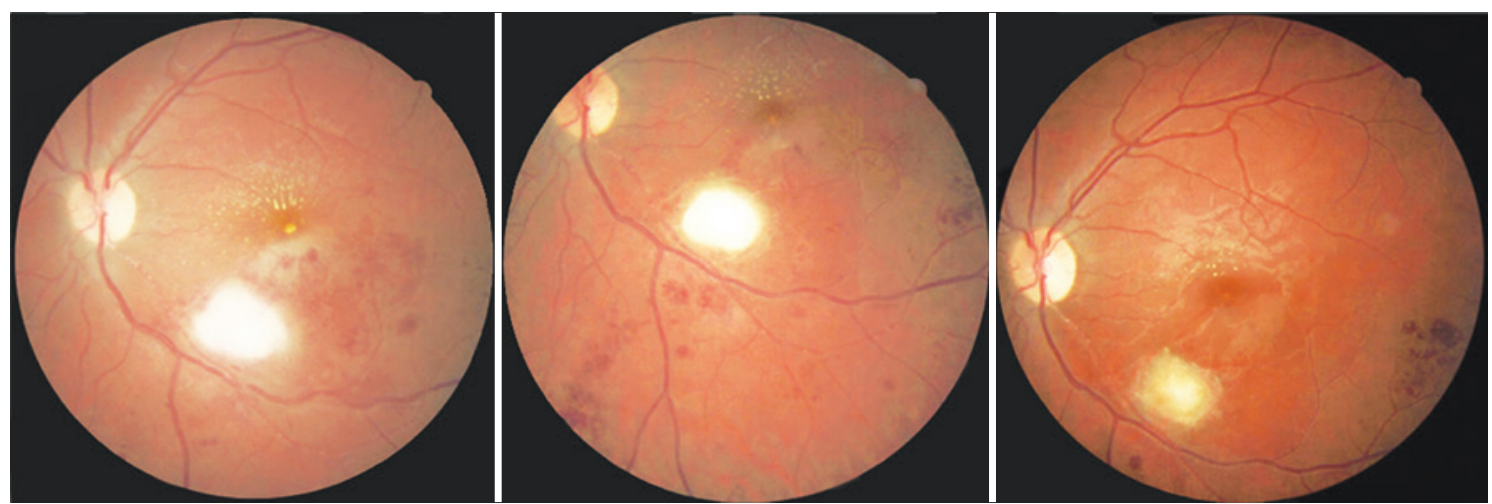

Figure 2. Fundus photography of the left eye at three weeks (left), six weeks (middle), and three months (right) after the beginning of treatment showing progressive improvement of the inferotemporal retinochoroidal lesion with complete scarring at the time of the last visit. A macular star is observed, as well as sheathing of the inferotemporal artery and numerous scattered hemorrhages. Periarterial plaques known as Kyrieleis arteritis can also be noted alongside the inferotemporal artery. 

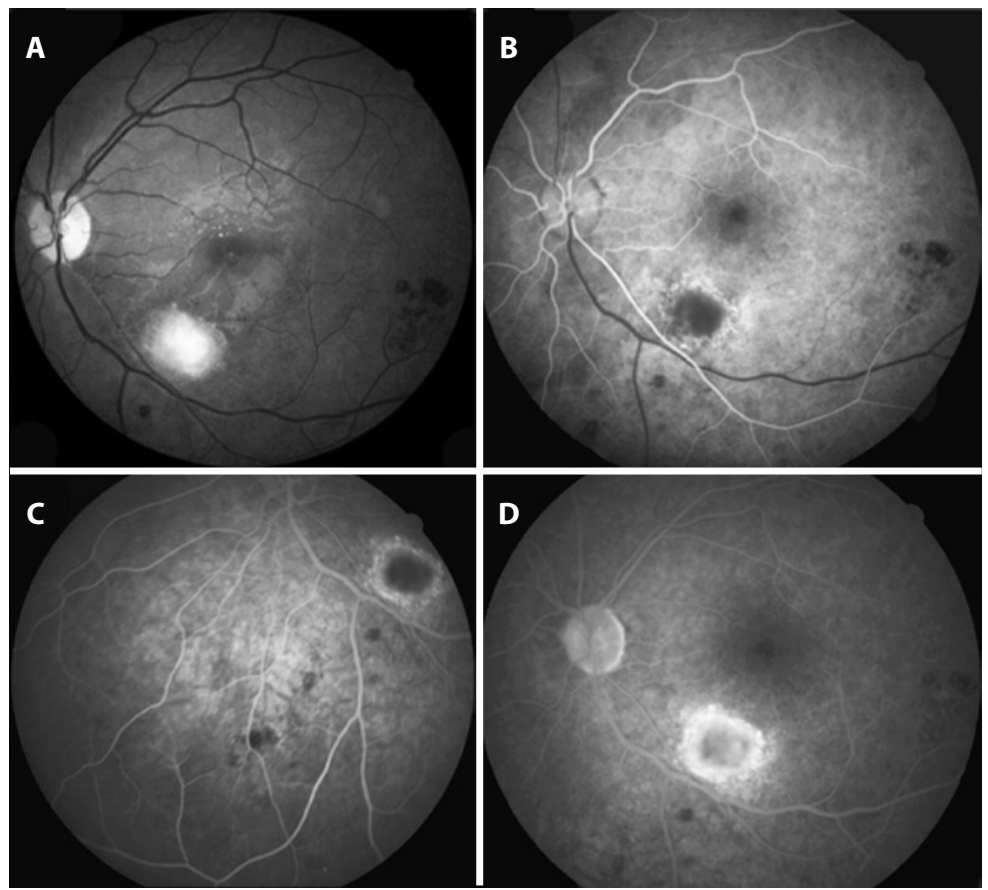

Figure 3. Fluorescein angiography $(F A)$ frames of the left eye three months after the beginning of treatment. (A) Red-free fundus photography. (B) Early FA frame disclosing hypofluorescence corresponding to the inferotemporal lesion surrounded by early hyperfluorescence. (C) Intermediate FA frame of the inferior region. No areas of non-perfusion are observed. (D) Late FA frame showing no leakage at the macular region. Blocked hypofluorescence is seen corresponding to the scattered retinal hemorrhages.

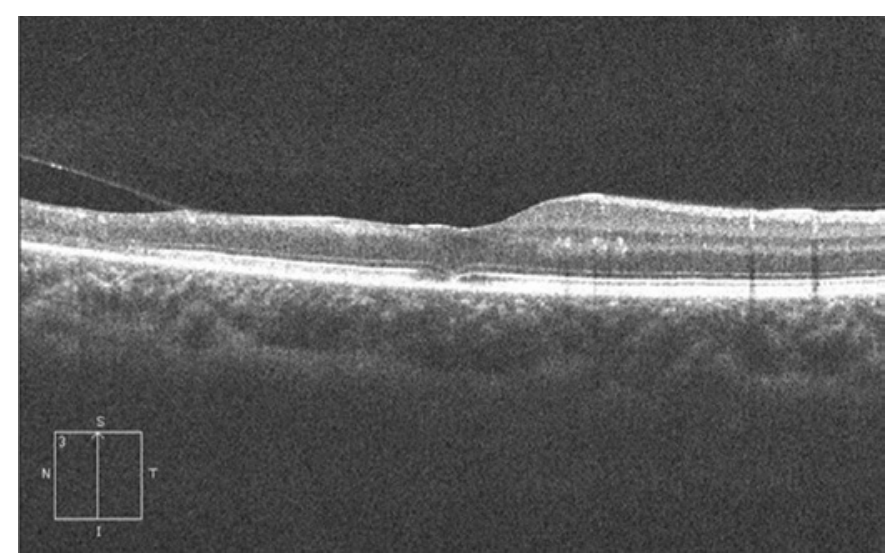

Figure 4. Vertical cross-sectional optical coherence tomography image of the left eye showing signs of partial posterior hyaloid detachment, inferior macular inner and middle retinal atrophy, hyperreflective intraretinal dots superior to the fovea, as well as mild foveal discontinuity of the outer retina and pigment epithelium layer.

ting ischemia of the intermediate and deep capillary plexuses, and (3) diffuse thickening and hyperreflectivity of the inner and middle retinal layers representing both superficial and deep capillary ischemia. In the chronic phase, thinning and atrophy of the affected retinal layers were seen. In our case, optical coherence tomography in the chronic phase revealed inner and middle inferior retinal macular atrophy, consistent with both superficial and deep capillary ischemia.

Atypical forms of ocular toxoplasmosis include punctate outer retinal toxoplasmosis, neuroretinitis, neuritis, pseudomultifocal retinochoroiditis, multifocal retinochoroiditis, peripheral lesions, and anterior uveitis ${ }^{(1)}$. Atypical presentations have been reported in patients with HIV infection, iatrogenic immunosuppression, or advanced age ${ }^{(8)}$. Moshfeghi et al. reported findings on 25 eyes with widespread retinochoroiditis mimicking acute retinal necrosis ${ }^{(8)}$. In their cases, lesions were atypical, large, multifocal, bilateral, or associated with diffuse retinal involvement or panophthalmitis. The diagnosis of toxoplasmosis was confirmed by the response to anti-toxoplasmosis medications, intraocular diagnostic studies such as polymerase chain reaction, intraocular antibody analysis, ocular fluid culture, or histopathological examination identifying Toxoplasma gondii in necrotic retinal tissue.

In conclusion, we report an uncommon presentation of toxoplasmosis, characterized by combined branch artery and vein occlusion, resulting in ischemic retinal whitening and numerous scattered retinal hemorrhages in the inferotemporal region along with a poorly defined proximal whitish retinal lesion. The possibility of toxoplasmosis in cases presenting with these features must be considered because prompt treatment may prevent a poor visual outcome.

\section{REFERENCES}

1. Oréfice F, Vasconcelos-Santos DV, Cordeiro CA, Oréfice $J$, Costa RA. Toxoplasmosis. In: Foster CS, Vitale AT. Diagnosis and treatment of uveitis. New Delhi, India: Jaypee Highlights; 2013. p.543-68.

2. Williamson TH, Meyer PA. Branch retinal artery occlusion in toxoplasma retinochoroiditis. Br J Ophthalmol. 1991:75(4):253.

3. Chiang E, Goldstein DA, Shapiro MJ, Mets MB. Branch retinal artery occlusion caused by toxoplasmosis in an adolescent. Case Rep Ophthalmol. 2012;3(3):333-8.

4. Arai H, Sakai T, Okano K, Aoyagi R, Imai A, Takase $H$, et al. Presumed toxoplasmic central retinal artery occlusion and multifocal retinitis with perivascular sheathing. Clin Ophthalmol. 2014;8:789-92.

5. Dubey JP, Lago EG, Gennari SM, Jones JL. Toxoplasmosis in humans and animals in Brazil: high prevalence, high burden of the disease, and epidemiology. Parasitology. 2012;139(11):1375-424.

6. Kahloun R, Mbarek S, Khairallah-Ksiaa I, Jelliti B, Yahia SB, Khairallah M. Branch retinal artery occlusion associated with posterior uveitis. J Ophthalmic Inflamm Infect. 2013;3(1):16.

7. Yu S, Pang CE, Gong Y, Freund KB, Yannuzzi LA, Rahimy E, et al. The spectrum of superficial and deep capillary ischemia in retinal artery occlusion. Am J Ophthalmol. 2015; 159(1):53-63.

8. Moshfeghi DM, Dodds EM, Couto CA, Santos Cl, Nicholson DH, Lowder CY, et al. Diagnostic approaches to severe, atypical toxoplasmosis mimicking acute retinal necrosis. Ophthalmology. 2004;111(4):716-25. 